\title{
Acute pancreatitis as first presentation of primary hyperparathyroidism: an observational study at tertiary care centre Jammu and Kashmir, India
}

\author{
Syed Mushfiq, Sheenam Gazala*, Ali Imran
}

Department of Medicine, Sher-i-Kashmir Institute of Medical Sciences, Soura, Srinagar, Jammu and Kashmir, India

Received: 15 December 2021

Revised: 05 January 2022

Accepted: 18 January 2022

\author{
*Correspondence: \\ Dr. Sheenam Gazala, \\ E-mail: sheeni8785@gmail.com
}

Copyright: (C) the author(s), publisher and licensee Medip Academy. This is an open-access article distributed under the terms of the Creative Commons Attribution Non-Commercial License, which permits unrestricted non-commercial use, distribution, and reproduction in any medium, provided the original work is properly cited.

\begin{abstract}
Metabolic causes of acute pancreatitis though uncommon, are important as early recognition helps in the management and prevention of recurrent episodes. Among the uncommon etiologies, Primary hyperparathyroidism (PHPT) is one of the important causes of acute pancreatitis. We studied nine patients with acute or recurrent acute pancreatitis with etiology of PHPT. All patients had elevated serum calcium on admission and high levels of circulating parathyroid hormone. Ultrasonography, 4D CT and Sestamibi scan was used to localize parathyroid adenoma. These patients underwent parathyroidectomy and post-operative histology was consistent with parathyroid adenoma.
\end{abstract}

Keywords: Hypercalcemia, Hyperparathyroidism, Pancreatitis

\section{INTRODUCTION}

Excessive alcohol consumption and gallstone related acute pancreatitis are by far the most common etiologies, both of which account around $70 \%$ of cases. The remaining $30 \%$ are those cases were not riggering even thus been mentioned. ${ }^{1-4}$

In these $30 \%$ of cases, $15 \%$ are said tobe idiopathic, while the rest cases are due to rare etiologies like anatomical variants, drugs, metabolic causes, infections, and genetic abnormalities. $^{5}$ The association of Primary hyperparathyroidism (PHPT) and acute pancreatitis is controversial. ${ }^{6}$ While alcohol and gallstones are the more common causes of acute pancreatitis.

Metabolic causes like hypocalcaemia and hypertriglyceridemia do account for a few.

Early recognition and treatment probably hold key to successful management, as associated pancreatitis if severe can have fatal consequences.

\section{CASE SERIES}

In this series, we present nine cases of acute pancreatitis (Table 1). Of nine patients, three had prior history of acute pancreatitis. None of them consumed alcohol. Evaluation for a metabolic cause revealed normal triglycerides but high serum calcium levels in all patients. Based on this suspicion of hypercalcemia related disease was thought in all these patients. Further evaluation revealed elevated intact parathyroid hormone in all.

For location of adenoma, Ultrasound neck (Figure 1), 4D CT neck and parathyroid scintigraphy (Figure 3 and 4) was done in patients and all had a lesion in neck which was suspicious of a parathyroid adenoma. All patients had mild acute pancreatitis as per modified Atlanta classifications, and organ failure were seen as per Marshall scores. Based on this, Patients were treated with hydration, analgesics and other supportive care. Later, then these patients subsequently underwent successful removal of the lesions. Macroscopic 
examination confirmed parathyroid adenoma in all patients (Figure 5). The patients have since been on

follow-up and are doing well.

Table 1: Cases of primary hyperparathyroidism with acute pancreatitis.

\begin{tabular}{|c|c|c|c|c|c|c|c|c|c|c|c|}
\hline $\begin{array}{l}\text { Age } \\
\text { /sex }\end{array}$ & $\begin{array}{l}\text { Pain } \\
\text { durat- } \\
\text { ion } \\
\text { (days) }\end{array}$ & $\begin{array}{l}\text { Previous } \\
\text { attack of } \\
\text { pancreas } \\
\text {-titis }\end{array}$ & $\begin{array}{l}\text { Seru } \\
\text { m } \\
\text { amyl- } \\
\text { ase } \\
\text { (U/l) }\end{array}$ & $\begin{array}{l}\text { Serum } \\
\text { PTH } \\
\text { (pg/ml) }\end{array}$ & $\begin{array}{l}\text { Vit D } \\
\text { levels } \\
\text { (ng/ml) }\end{array}$ & $\begin{array}{l}24 \mathrm{hr} \\
\text { Urinary } \\
\text { cal (mg) }\end{array}$ & USG & $\begin{array}{l}\text { 4D } \\
\text { CT }\end{array}$ & $\begin{array}{l}\text { Nuc- } \\
\text { lear } \\
\text { scan }\end{array}$ & $\begin{array}{l}\mathbf{H P} \\
\mathbf{E}\end{array}$ & $\begin{array}{l}\text { Post-op } \\
\text { calcium }\end{array}$ \\
\hline $\begin{array}{l}58 / \\
\text { F }\end{array}$ & 3 & No & 1340 & 736 & 15.1 & 308 & $\begin{array}{l}\text { Left } \\
\text { infer- } \\
\text { ior }\end{array}$ & $\begin{array}{l}\text { Not } \\
\text { done }\end{array}$ & $\begin{array}{l}\text { Same } \\
\text { as } \\
\text { USG }\end{array}$ & $\begin{array}{l}\text { Ad- } \\
\text { en- } \\
\text { oma }\end{array}$ & 9.54 \\
\hline $\begin{array}{l}25 / \\
\text { F }\end{array}$ & 2 & No & 3345 & 97 & 3.6 & 247 & $\begin{array}{l}\text { Right } \\
\text { infer- } \\
\text { ior }\end{array}$ & $\begin{array}{l}\text { Not } \\
\text { done }\end{array}$ & $\begin{array}{l}\text { Same } \\
\text { as } \\
\text { USG }\end{array}$ & $\begin{array}{l}\text { Ad- } \\
\text { en- } \\
\text { oma }\end{array}$ & 9.65 \\
\hline $\begin{array}{l}60 / \\
M\end{array}$ & 10 & No & 2398 & 338 & 60.5 & 370 & $\begin{array}{l}\text { Right } \\
\text { infer- } \\
\text { ior }\end{array}$ & $\begin{array}{l}\text { Not } \\
\text { done }\end{array}$ & $\begin{array}{l}\text { Same } \\
\text { as } \\
\text { USG }\end{array}$ & $\begin{array}{l}\text { Ad- } \\
\text { en- } \\
\text { oma }\end{array}$ & 9.85 \\
\hline $\begin{array}{l}58 / \\
\text { F }\end{array}$ & 2 & Yes & 345 & 74 & 72.9 & 450 & $\begin{array}{l}\text { Not } \\
\text { loca- } \\
\text { lis- } \\
\text { ed }\end{array}$ & $\begin{array}{l}\text { Right } \\
\text { inferi } \\
\text { or }\end{array}$ & $\begin{array}{l}\text { Ri- } \\
\text { ght } \\
\text { in- } \\
\text { fer- } \\
\text { ior }\end{array}$ & $\begin{array}{l}\text { Ad- } \\
\text { en- } \\
\text { oma }\end{array}$ & 8.45 \\
\hline $\begin{array}{l}62 / \\
F\end{array}$ & 4 & No & 3451 & 487 & 13.5 & 103 & $\begin{array}{l}\text { Left } \\
\text { sup- } \\
\text { eri- } \\
\text { or }\end{array}$ & $\begin{array}{l}\text { Same } \\
\text { as } \\
\text { USG }\end{array}$ & $\begin{array}{l}\text { Not } \\
\text { done }\end{array}$ & $\begin{array}{l}\text { Ad- } \\
\text { en- } \\
\text { oma }\end{array}$ & 9.56 \\
\hline $\begin{array}{l}75 / \\
M\end{array}$ & 2 & No & 758 & 2500 & 11.2 & 347 & $\begin{array}{l}\text { Left } \\
\text { inferi } \\
\text { or }\end{array}$ & $\begin{array}{l}\text { Same } \\
\text { as } \\
\text { USG }\end{array}$ & $\begin{array}{l}\text { Not } \\
\text { Done }\end{array}$ & $\begin{array}{l}\text { Ade } \\
\text { nom } \\
\text { a }\end{array}$ & 8.76 \\
\hline $\begin{array}{l}\mathbf{5 0 /} \\
\text { F }\end{array}$ & 6 & Yes & 875 & 109 & 26.5 & 724 & $\begin{array}{l}\text { Left } \\
\text { Infer- } \\
\text { ior }\end{array}$ & $\begin{array}{l}\text { Same } \\
\text { as } \\
\text { USG }\end{array}$ & $\begin{array}{l}\text { Same } \\
\text { as } \\
\text { USG }\end{array}$ & $\begin{array}{l}\text { Ad- } \\
\text { eo- } \\
\text { ma }\end{array}$ & 8.88 \\
\hline $\begin{array}{l}45 / \\
M\end{array}$ & 7 & No & 457 & 361 & 36.4 & 340 & $\begin{array}{l}\text { Right } \\
\text { inferi } \\
\text { or }\end{array}$ & $\begin{array}{l}\text { Same } \\
\text { as } \\
\text { USG }\end{array}$ & $\begin{array}{l}\text { Same } \\
\text { as } \\
\text { USG }\end{array}$ & $\begin{array}{l}\text { Ad- } \\
\text { en- } \\
\text { oma }\end{array}$ & 9.70 \\
\hline $\begin{array}{l}40 / \\
F\end{array}$ & 1 & Yes & 1245 & 209 & 71.2 & 298 & $\begin{array}{l}\text { Not } \\
\text { local } \\
\text { is- } \\
\text { ed }\end{array}$ & & $\begin{array}{l}\text { Le- } \\
\mathrm{ft} \\
\text { in- } \\
\text { fer- } \\
\text { ior }\end{array}$ & $\begin{array}{l}\text { Ad- } \\
\text { en- } \\
\text { oma }\end{array}$ & 8.12 \\
\hline
\end{tabular}

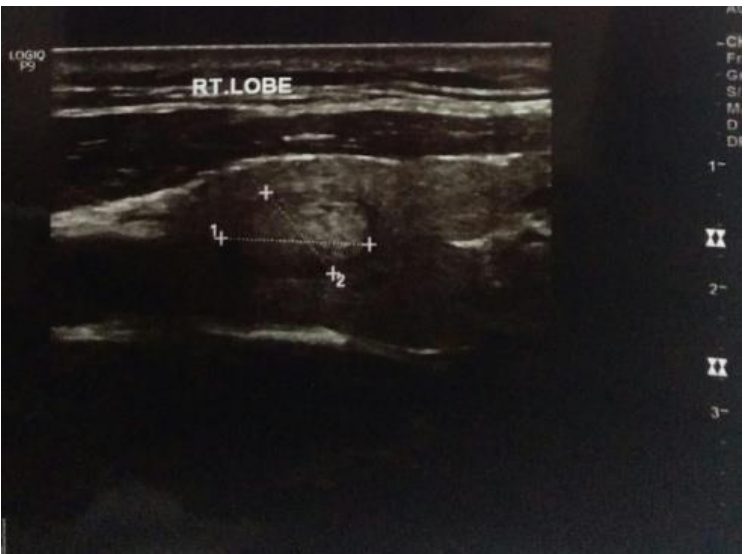

Figure 1: USG showing parathyroid adenoma.
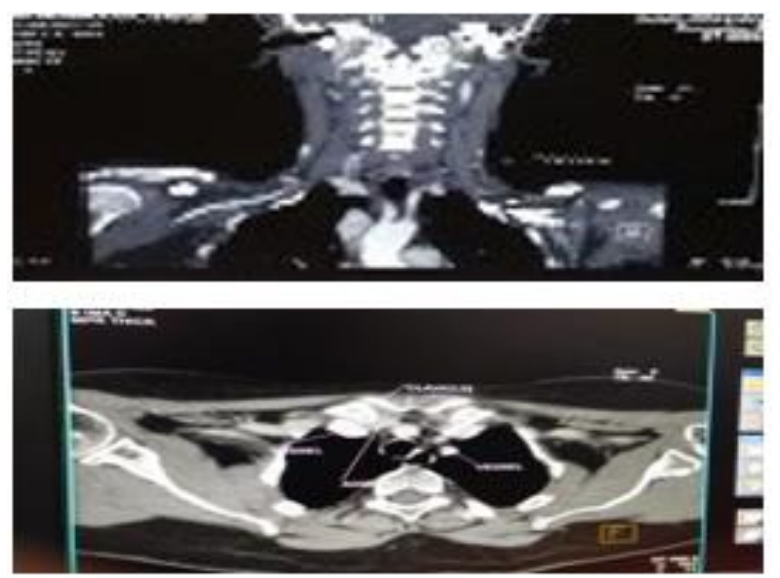

Figure 2: 4D-CECT showing parathyroid adenoma. 


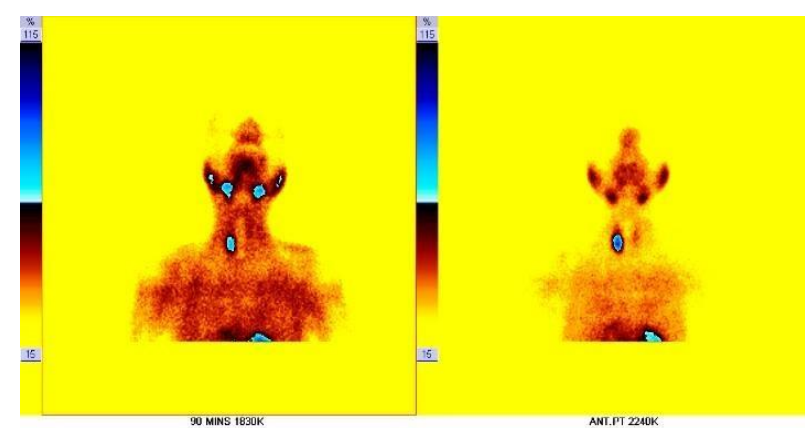

Figure 3: Parathyroid scan showing right parathyroid adenoma.

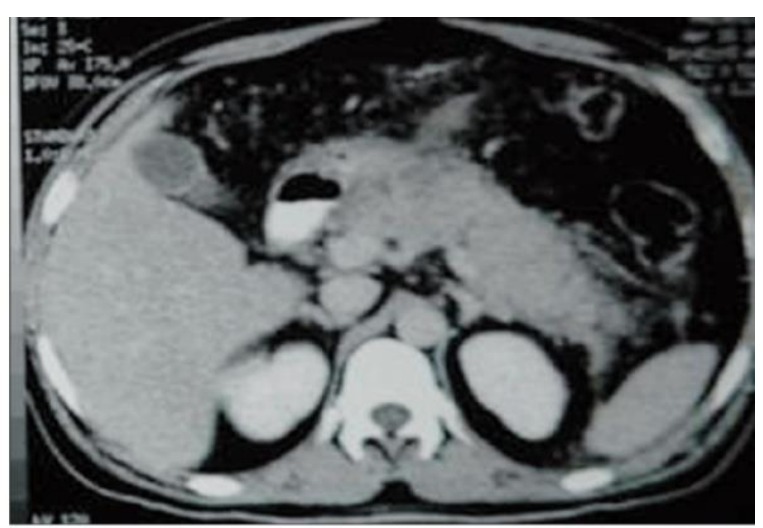

Figure 4: CECT showing bulky pancreas.

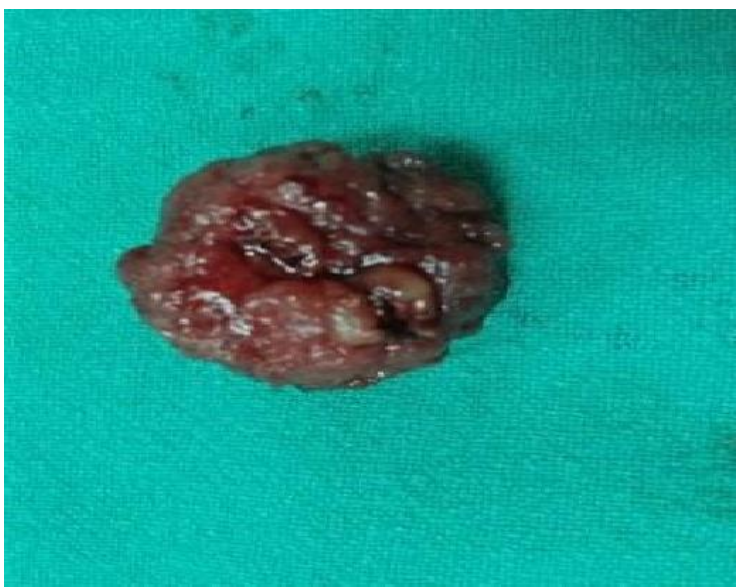

Figure 5: Excision of parathyroid adenoma.

\section{DISCUSSION}

Acute pancreatitis is an inflammatory process of pancreas characterized by systemic inflammatory response syndrome, local injury, and organ failures.

This disease is one of the most common gastroenterological condition that leads to severe sufferings, morbidity, and mortality. Diagnosis of acute pancreatitis require two among the following three features: (a) pancreatic type abdominal pain; (b) greater than three-folds elevation of serum amylase or lipase titers; and (c) features suggestive of acute pancreatitis on cross-sectional imaging. The etiology of AP can be readily established in most patients. The most common cause of AP is gallstones (40-70\%) and alcohol (25$35 \%) .{ }^{1-4}$ In the absence of alcohol or gallstones, caution must be exercised when attributing a possible etiology for AP to another agent or condition. Medications, infectious agents, and metabolic causes such as hypercalcemia and hyperparathyroidism are rare causes, often falsely identified as causing AP. ${ }^{7-9}$ Among these rare ones, PHPT accounts less than $0.5 \%$ of all cases of acute pancreatitis, and the incidence of acute pancreatitis in patients with hyperparathyroidism varies from $0.5 \%$ to $1.5 \%$.

The mechanism by which PHPT leads to acute pancreatitis is unclear. Carnaille et al suggested that elevated serum calcium level is responsible for the development of pancreatitis inpatients with PHPT. ${ }^{10}$ The molecular mechanism of hypercalcemia are gradually being resolved. Proposed mechanisms include premature activation of pancreatic protease leading to acute pancreatitis and deposition of calcium salts. ${ }^{6}$ Calcium is important for intracellular signally and homeostasis. Disturbances in intracellular calcium levels impair its signally functions and high cytosolic levels within the exocrine acinar cells trigger premature protease activation. ${ }^{11}$ Blocking the uptake of calcium into the cells or chelation of intracellular ionized calcium largely prevents digestive zymogen activation and pancreatic damage.

Estimation of serum calcium holds the key to early diagnosis and treatment. Identifying hypercalcemia during an episode of acute pancreatitis may pose a problem as calcium levels may be low during the attack. ${ }^{12}$ Therefore, it is important to recheck calcium levels after resolution of acute pancreatitis especially in patients with idiopathic recurrent acute pancreatitis. PHPT and malignancy account for approximately $90 \%$ of cases of hypercalcemia. ${ }^{13}$ Elevated intact parathyroid hormone helps distinguish the two. Elevated iPTH is usually found in PHPT and once after the diagnosis of PHPT is labelled, the next step one has to go imaging to localize the source of PTH secretion. Radio nuclides cintigraphy and ultrasonography are the most common pre-operative tests used for localization of parathyroid glands. The treatment for hypercalcemia includes hydration with normal saline, forced diuresis, bisphosphonates, calcitonin, oral phosphates, glucocorticoids, and dialysis.

All these patients were managed by giving IV fluids for first 24 hours, after volume expansion, diuretics can be used. The underlying PHPT can be cured by surgery. ${ }^{14}$ In patients with acute pancreatitis, surgery should be performed early so as to prevent recurrent episodes of acute pancreatitis.

Several clinical trials have been set-up to investigate the possibility of reducing the incidence and severity of 
pancreatitis by interfering with the intracellular effects of calcium, although not being a definite therapy.

\section{CONCLUSION}

From our study we conclude that hyperparathyroidism though not common cause of acute pancreatitis, while as early recognition by biochemical and radiological means help in early management and prevention of recurrent episodes of acute pancreatitis. Early management of hypercalcemia along with underlying etiology like excision of parathyroid adenoma results in reduced episodes of acute pancreatitis. Hyperparathyroidism related pancreatitis are usually mild as compared to pancreatitis secondary to other causes. Usually all had mild to moderate elevations of serum calcium. None of our patients had life threatening hypercalcemia. All patients had parathyroid adenoma as an etiology for elevated PTH.

Funding: No funding sources

Conflict of interest: None declared

Ethical approval: Not required

\section{REFERENCES}

1. Lankisch PG, Assmus C, Lehnick D, Maisonneuve P, Lowenfels AB. Acute pancreatitis: does gender matter?. Dig Dis Sci. 2001;46(11):2470-4.

2. Gullo L, Migliori M, Oláh A, Farkas G, Levy P, Arvanitakis C, et al. Acute pancreatitis in five European countries: etiology and mortality. Pancreas. 2002;24(3):223-7.

3. Lowenfels AB, Maisonneuve P, Sullivan T. The changing character of acute pancreatitis: epidemiology, etiology, and prognosis. Curr Gastroenterol Rep. 2009;11:97-103.

4. Johnson C, Lévy P. Detection of gallstones in acute pancreatitis: when and how? Pancreatology. 2010;10(1):27-32.
5. Magno MJ, Di EP. Pancreas divisum does not cause pancreatitis, but associates with CFTR mutations. Am J Gastroenterol. 2012;107:318-20.

6. Bai HX, Giefer M, Patel M, Orabi AI, Husain SZ. The association of primary hyperparathyroidism with pancreatitis. J Clin Gastroenterol. 2012;46:65661.

7. Badalov N, Baradarian R, Iswara K. Drug induced acute pancreatitis: an evidence based approach. Clin Gastroenterol Hepatol. 2007;101:454-76.

8. Fortson MR, Freedman SN, Webster PD. Clinical assessment of hyperlipidemic pancreatitis. Am J Gastroenterol. 1995;90(12):2134-9.

9. Parenti DM, Steinberg W, Kang P. Infectious causes of acute pancreatitis. Pancreas. 1996;13(4):356-71.

10. Carnaille B, Oudar C, Pattou F, Combemale F, Rocha J, Proye C. Pancreatitis and primary hyperparathyroidism: forty cases. Aust NZJ Surg. 1998;68:117-9.

11. Kruger B, Abrecht E, Lerch MM. The role of intracellular calcium signally in premature protease activation and on set of pancreatitis. Am J Pathol. 2000;157(1):555-8.

12. Ammori BJ, Barclay GR, Larvin M, McMahon MJ. Hypocalcemia in patients with acute pancreatitis: a putative role for systemic endotoxin exposure. Pancreas. 2003;26(3):213-7.

13. Lafferty FW. Differential diagnosis of hypercalcemia. J Bone Miner Res. 1991; 6(2):51-9.

14. Suliburk JW, Perrier ND. Primary hyperparathyroidism. Oncologist. 2007;12(6):64453.

Cite this article as: Mushfiq S, Gazala S, Imran A. Acute pancreatitis as first presentation of primary hyperparathyroidism: an observational study at tertiary care centre Jammu and Kashmir, India. Int J Adv Med 2022;9:153-6. 